EPiC Series in Language and Linguistics
Volume 2, 2017, Pages $82-91$
Professional and Academic Discourse:
an Interdisciplinary Perspective

\title{
Challenges in Task Design for Learners of Russian with a Low Level of Proficiency
}

\author{
Elena Markina \\ University of Barcelona, Barcelona, Spain \\ imarkima7@alumnes.ub.edu
}

\begin{abstract}
The goal of this paper is to analyze some of the issues related to task design in Russian on the basis of a pilot study carried out with 19 bilingual Catalan- and Spanish-speaking participants. They performed six form-focused tasks targeted at the use of case forms and verbs of movement in Russian. Although some problems in task design were detected, $t$ test showed that learners improved significantly in the use of the target forms.

Keywords: Task-Based Language Teaching, task complexity, focus on form, Russian as a foreign language
\end{abstract}

\section{Introduction}

The goal of this paper is to discuss the results of a pilot study that was carried out as a part of my $\mathrm{PhD}$ research at the University of Barcelona and to analyze some of the issues related to task design in Russian as a foreign language.

In the last few decades Task-Based Language Teaching (TBLT) has become one of the most important approaches to language teaching and second language acquisition (SLA) research (Ellis, 2003); (Long, 2015); (Nunan, 2004); (Robinson, 2011); (Skehan, 1998), among others). The main difference of TBLT from traditional linguistic syllabi is that "rather focusing on the explicit, discrete knowledge of specific aspects of language in isolation, and building up proficiency in an incremental, step-by-step fashion, task-based work aims to feed the learner's internal syllabus while engaging the learner in holistic communicative use of language” (Van den Branden K. , 2013, p. 628). Task, which is the central unit of syllabus design in TBLT, can be characterized as an activity in which:

- meaning is primary;

- $\quad$ there is some kind of communication problem to solve;

- there is some sort of relationship to comparable real-world activities;

- the assessment of the task is in terms of outcome (Skehan, 1998).

Robinson (Robinson, 2011) argued that tasks provide a context for negotiating and comprehending the meaning of language; they provide opportunities for the uptake of corrective feedback, for the incorporation of input containing positive evidence and for noticing the gap between a participant's 
production and the target language. However, until now, most TBLT research has been done for English, and there is not enough evidence of how task-based courses should be designed for languages with a different grammar structure, as in the case of Russian. Therefore, there is a need to prove if the TBLT approach may actually provide effective teaching practices in Russian.

In contrast to English, in which lexical encoding may receive most of the learner's attention during message formulation and comprehension, the morphological complexity of Russian demands to switch attention to morphosyntactic encoding that increases the linguistic complexity of tasks. This difference between Russian and English can be illustrated through "Object placing" task, which consists of describing the location of different objects in a room. In the case of English, the linguistic difficulty of the task is mostly lexical and consists of learning necessary lexical items. Learners of Russian have an additional grammar load, as they deal with case forms that follow each preposition, and have to decline nouns and adjectives. It is particularly difficult for low proficiency students because the case forms are still not automated either for production or comprehension. It means that performing this task in Russian requires more attention and effort than in English.

The morphological complexity of Russian conditions the design of tasks and teaching strategies since both cognitive and linguistic factors must be taken into account. Robinson's model of task complexity (Robinson, 2001), widely accepted in TBLT research, includes cognitive, interactive, and learner factors, but it doesn't mention linguistic factors (see Table 1). They are presented in Skehan's model of task difficulty (Table 2), which includes the concept of code complexity (Skehan, 1998). Robinson's approach better organizes the elements that must be taken into account in syllabus design, since a larger number of task complexity features can be operationalized separately. For this reason, it is more appropriate for research purposes. However, due to the morphological complexity of Russian, code difficulty cannot be ignored and should be considered as a factor of task complexity.

\begin{tabular}{|l|l|l|}
\hline $\begin{array}{c}\text { Task complexity } \\
\text { (Cognitive factors) }\end{array}$ & \multicolumn{1}{|c|}{$\begin{array}{c}\text { Task condition } \\
\text { (Interactive factors) }\end{array}$} & $\begin{array}{c}\text { Task difficulty } \\
\text { (Learner factors) }\end{array}$ \\
\hline Resource directing & Participation variables & Affective variables \\
+/- few elements & one-way/two-way & motivation \\
+/- here-and-now & convergent/divergent & anxiety \\
+/- no reasoning demands & open/closed & confidence \\
Resource dispersing & Participant variables & Ability variables \\
+/- planning time & gender & aptitude \\
+/- single task & familiarity & proficiency \\
+/- prior knowledge needed & power/solidarity & intelligence \\
\hline
\end{tabular}

Table 1: Robinson's model of task complexity (2001)

\begin{tabular}{|l|l|l|}
\hline \multicolumn{1}{|c|}{ Cognitive complexity } & \multicolumn{1}{|c|}{ Code complexity } & Communicative stress \\
\hline Cognitive familiarity & Linguistic complexity & Time pressure \\
Familiarity of topic & and variety & Scale \\
Familiarity of discourse & Vocabulary load and & Number of participants \\
genre & variety & Length of text used \\
Familiarity of task & & Modality \\
Cognitive processing & & Stakes \\
Information organization & & Opportunity for control \\
Amount of computation & & \\
Clarity of information & & \\
Sufficiency of information & & \\
\hline
\end{tabular}

Table 2: Skehan’s model of task difficulty (1998) 


\section{Research Questions}

Following Robinson's model of task complexity with the addition of code complexity factor, 6 tasks were designed for the experimental task-based treatment. Its objective was to test the tasks in order to answer the following questions:

1. Is the chosen level of task complexity feasible for learners?

2. To what extent can focus-on-form techniques, used in the tasks, help draw the learners' attention to the target forms?

\section{Participants}

The participants of the pilot study were 19 (15 females, 4 males) Catalan- and Spanish-native speakers enrolled in the program "Modern Languages and Literature" at the University of Barcelona. At the moment the study started, the learners had been exposed to approximately 80 hours of instruction.

The pilot study was carried out in classroom conditions. First, a pre-test was carried out with the group of "Russian Language I" (Rus I). Then eight sessions (14 hours in total) took place. An immediate post-test followed these sessions. The same procedure (a pre-test - 8 sessions - and an immediate posttest) was repeated four months later with the students of Rus I who continued learning Russian and formed the group of "Russian Language II" (Rus II).

\section{Target Items}

The pilot study was integrated into the university curriculum, for this reason, the target items were predetermined by the program of the university courses "Russian Language I" and "Russian Language II". Following the Russian language syllabi, the first part of the experiment was focused on the Russian case system (Table 3), and the second part included verbs of movement, corresponding prepositions, and case forms (Table 4). Learners were familiar with some target items, and others were new to them. 


\begin{tabular}{|c|c|}
\hline New target items & Target forms seen before the treatment \\
\hline $\begin{array}{l}\text { I. Use of case forms after prepositions and } \\
\text { verbs } \\
\text { 1. В/На (in/on) + Prepositional Case } \\
\text { (expression of time: week, month, year). } \\
\text { 2. O (about) + Prepositional Case. } \\
\text { 3. Без (without), для (for), из (from), около } \\
\text { (near), слева от (to the left of), справа от (to the } \\
\text { right of), напротив (in front of), в центре (in } \\
\text { the center of) + Genitive Case. } \\
\text { 4. К (to + person) + Dative Case. } \\
\text { II. Который (which) }\end{array}$ & $\begin{array}{l}\text { 1. Accusative Case } \\
\text { - direct object; } \\
\text { - B/нa (to); } \\
\text { - B (on) + days of week. } \\
\text { 2. Prepositional Case } \\
\text { - B/Ha (in/on/at); } \\
\text { - Ha (by) + means of transport. } \\
\text { 3. Genitive Case } \\
\text { - possession; } \\
\text { - absence; } \\
\text { - expression of quantity (after numerals and } \\
\text { adverbs). } \\
\text { 4. Dative Case } \\
\text { - indirect object; } \\
\text { - age; } \\
\text { - in constructions Мне нравится (I like), } \\
\text { Мне нужно (I need). } \\
\text { 5. Instrumental Case } \\
\text { - C (with); } \\
\text { - after verbs быть (to be), работать (to } \\
\text { work), стать (to become), заниматься (to } \\
\text { do); } \\
\text { - expression of time (seasons and parts of the } \\
\text { day). }\end{array}$ \\
\hline
\end{tabular}

Table 3: Russian Case System (Rus I) 


\begin{tabular}{|c|c|}
\hline New target items & $\begin{array}{l}\text { Target forms seen before the } \\
\text { treatment }\end{array}$ \\
\hline $\begin{array}{l}\text { I. Verbs of movement with the prefixes } \\
\text { приходить - прийти } \\
\text { приезжать - приехать (come) } \\
\text { уходить - уйти } \\
\text { уезжать - уехать (leave) } \\
\text { доходить - дойти } \\
\text { доезжать - доехать (reach) } \\
\text { проходить - пройти } \\
\text { проезжать - проехать (pass by) } \\
\text { входить - войти (enter) } \\
\text { выходить - выйти (go out) } \\
\text { заходить - зайти (drop in) } \\
\text { переходить - перейти (cross) } \\
\text { II. Рreроsitions and corresponding case } \\
\text { forms } \\
\text { 1. Из (from), мимо (by), до (to) + Genitive } \\
\text { Саse. } \\
\text { 2. Через (through) + Асcusative Case. } \\
\text { III. Поворачивать - повернуть (to turn), } \\
\text { налево (to the left), направо (to the right), прямо } \\
\text { (straight). }\end{array}$ & $\begin{array}{l}\text { I. Verb to go } \\
\text { идти-ходить, ехать-ездить, пойти, } \\
\text { поехать } \\
\text { II. Prepositions and corresponding } \\
\text { case forms } \\
\text { 1. В/на (to) + Accusative Case } \\
\text { (direction); } \\
\text { 2. В/на (in, on, at) + Prepositional Case } \\
\text { (place); } \\
\text { 3. На (by) + Prepositional Case (means of } \\
\text { transport); } \\
\text { 4. По (along, by) + Dative Case; } \\
\text { 5. Около (near), слева от (to the left of), } \\
\text { справа от (to the right of), напротив (in front } \\
\text { оf), в центре (in the center of) + Genitive } \\
\text { Саsе; } \\
\text { 6. Перед (in front of), за (behind), под } \\
\text { (under), над (above), между (between), } \\
\text { рядом с (nехt to) + Instrumental Case. }\end{array}$ \\
\hline
\end{tabular}

Table 4: Verbs of Movement (Rus II)

\section{Task Design and Sequence}

The tasks in the pilot study were designed taking into account the following factors:

- the learners' previous linguistic knowledge and their current level of proficiency,

- their basic language needs,

- the target forms and vocabulary.

A short description of tasks used in the study is given below. The tasks are presented in the order in which they were implemented in the classroom.

\section{What is the film about?}

Write synopses of three films so that other students in the group could guess what films you are talking about. Use the key words for help.

\section{Menu for the day}

Six people come to stay with you. Prepare a detailed menu for each of them for one day. Write what they are going to eat and drink for breakfast, lunch, and supper. Take into account that they have special needs and preferences (a child, a sportsman, a vegetarian, a pregnant woman, a person on a diet, and a millionaire). 


\section{Agenda}

Make a plan for the day. Tell when and where you have to go and who you have to see. Take into account the following information: you have a toothache and the dentist starts to work at 14; your friend invited you to a restaurant at 21 , etc.

\section{Object placing}

You work in pairs and have a picture of the same room with some objects missing. You are allowed to look only at your picture and not at your partner's picture. Ask your partner if he or she sees the objects that you see and, if not, you must explain where they are located.

\section{How to get to...?}

You and your partner have a map of the city center in St. Petersburg. Explain to him/her the route that is marked in your map. Your partner has to follow your instructions and draw the route on his/her map.

\section{Library schedule}

Six students worked in the university library last week. Each student worked 10 hours. You have to fill in the table of library attendance on the base of information that you and your partners have. Say when each of the students worked in the library.

The tasks were sequenced according to task complexity including cognitive and linguistic factors. The cognitive load of all the tasks was decreased as much as possible (a low number of participants, no time pressure, and familiar situations and topics) in order to have the learners' attention directed to the language forms. The cognitive factors that varied from task to task were a number of elements, +/- Hereand-Now, +/- reasoning demands, and single or dual tasks. The last task of the pilot study, Library schedule, imposed more cognitive load on the learner than the other tasks. It implicated reasoning demands (simple logical and mathematical operations in order to calculate the hour of arrival of some students to the library), There-and-Then condition, dual task, a high number of elements (6 possible hour frames in 5 days for 4 students).

With regard to code complexity, task sequence was determined by the number of new task-essential grammar forms. For example, in the first task (What is the film about?) only the preposition about and the form of Prepositional case after it were new for learners. In the second task, learners had to use at least three forms: Accusative case to express the direct object; preposition with + Instrumental case; prepositions for and without + Genitive case.

\section{Focus on Form}

In order to draw the learners' attention to the target forms, different focus-on-form techniques were used. First, in task design the preference was given to information gap and jigsaw tasks that, according to the previous studies (Pica, T., Kanagy, R., Falodun, J., 1993), promoted negotiation of meaning. Second, tasks were designed in such a way that most target forms were task-essential, that is, a successful performance of the task was not possible without using these forms (Loschky, L., BleyVroman, R., 1993).

Focus-on-form techniques were also used in the presentation of input. Texts in the pre-task were flooded with target items (input flooding), which were typed in bold (input enhancement). In some cases, input elaboration was used in order to introduce and explain new vocabulary and to draw the learners' attention to task-useful or task-essential lexical items. During task performance when learners worked in pairs or small groups, they used clarification requests (Long 1983) to negotiate the meaning. When learners reported the results of their work, the teacher used recasts (repetition of learner's words corrected by the teacher) and explicit error correction in order to draw the learners' attention to wrong 
forms. Direct instruction (for example, a short rule explanation) was used only when learners asked for it in the process of communication.

\section{Problems in Task Performance}

From 6 pilot tasks learners struggled a lot while performing the task "What is the film about?" and failed to perform "Library schedule" task. The observation of learners doing these tasks helped to detect the following problems in task design and implementation:

- Learners didn't know well or could not use properly lexical items they were expected to know (for example, numerals or the days of the week). Together with difficulty of using new grammatical forms, it increased the code complexity of both tasks to such a degree that most students couldn't perform them successfully. Some students did achieve a task outcome, but they used their L1 a lot.

- A high number of elements in "Library schedule" task (six possible hour frames in five days for four students) and reasoning demands (simple logical or mathematical operations) increased its cognitive complexity to such an extent that it was not feasible for learners. It was obvious that code complexity took so much attention that learners could not handle other variables of the task.

- In the task "What is the film about?" students focused mostly on meaning and didn't notice target grammar forms. They used correctly the preposition o (about), essential for the task completion, but did not pay attention to the forms of Prepositional case that are obligatory after this preposition. For this reason, their production was quite inaccurate.

The observation showed that, on the one hand, these two tasks had to be simplified in terms of language requirements and cognitive load, and, on the other hand, more pre-task activities were needed.

\section{Tests}

The pre-test and post-test consisted of grammar tests and a written task where the use of the target forms was task-essential. Data collection was carried out twice: with the learners of Rus I and the learners of Rus II. Learners had one hour and a half to do the test. They were not allowed to use any teaching materials or dictionaries.

Grammar tests were of three types: 1) fill in the blanks, 2) a multiple-choice test, and 3) grammaticality judgment test. The written task for learners of the group Rus I was to answer a friend's letter and tell about their vacations and last trip. Learners of Rus II were asked to write an email inviting their Russian friends to a birthday party and a picnic (Table 5). The word limit in both the pre-test and the post-test was between 120 and 150 words. 


\begin{tabular}{|c|c|}
\hline Pre-test & Post-test \\
\hline \multicolumn{2}{|c|}{ Rus I } \\
\hline $\begin{array}{l}\text { You received a letter from your Russian } \\
\text { friend. He asks you about your last trip. Write } \\
\text { him an answer and tell about: } \\
\text { - when, where and with whom you went, } \\
\text { - what you saw, } \\
\text { - where you lived, } \\
\text { what you had and didn't have in your } \\
\text { room, } \\
\text { - what you bought, } \\
\text { what you liked and what you didn't } \\
\text { like in your trip. }\end{array}$ & $\begin{array}{l}\text { You received a letter from your Russian } \\
\text { penpal. He tells you about his winter vacations } \\
\text { and asks how you spent yours. Write him a letter } \\
\text { answering all of his questions. } \\
\text { - When did you have your winter } \\
\text { vacations, and how long were they? } \\
\text { - What did you do? } \\
\text { - Where did you go? } \\
\text { - What's the weather like in your city in } \\
\text { - What do you like to do in winter? } \\
\text { - was it about? last film that saw? What like it? } \\
\text { Do you like music? What is your } \\
\text { favorite music band? }\end{array}$ \\
\hline \multicolumn{2}{|r|}{ Rus II } \\
\hline $\begin{array}{l}\text { You want to invite your Russian friends to } \\
\text { your birthday party. They have never been in } \\
\text { your home and they don't know how to get } \\
\text { there. Write them an email where you should tell } \\
\text { them: } \\
\text { - what day and what time they have to } \\
\text { come, } \\
\text { your home address (street, house), the } \\
\text { nearest metro station, } \\
\text { how to get from the metro to your } \\
\text { home (which exit to take, what } \\
\text { buildings to pass by), } \\
\text { - what you want to cook for dinner, } \\
\text { where you want to go to after the } \\
\text { dinner. }\end{array}$ & $\begin{array}{l}\text { You are organizing a picnic in the Ciutadella } \\
\text { Park and you want to invite your Russian } \\
\text { friends. It is their first time in Barcelona and } \\
\text { they don't know where the park is. Write them } \\
\text { an email where you should tell them: } \\
\text { - what day and what time the picnic will } \\
\text { be, } \\
\text { - how to get to the park, } \\
\text { - what they should bring (drinks, food), } \\
\text { (your friends, family), } \\
\text { - where you want to go after the picnic. }\end{array}$ \\
\hline
\end{tabular}

Table 5: Written tasks in the pre-test and the post-test

\section{Results}

The data obtained in the pre-tests and post-tests from both groups were statistically analyzed in order to answer the question about the efficiency of focus-on-form techniques used in the tasks. The ShapiroWilk test showed that the data followed normal distribution. As two related samples had to be compared, the student's $t$-test was used in order to determine whether there were significant differences in using the target forms in the pre- and post-test. To perform statistical analyses, the statistical package for the social sciences (SPSS) 19 was used. An alpha level of $\mathrm{p}<.05$ was set for all the tests.

For assessment of the written production, target-like use (TLU) of case forms (for Rus I) and verbs of movement (for Rus II) was calculated by dividing the number of accurately used target items by the total number of produced target items, and then multiplying that number by 100 .

The $T$-test showed that in the group Rus I learners achieved significant differences in all the tests (fill in the blanks (FB), the multiple choice test (MC) and use of the target forms (TLU) in the written 
production) with the exception of the grammaticality judgement (GJ) test. For the group Rus II the $T$ test confirmed that there were statistically significant differences between the pre- and post-tests for all the tests (see Table 6).

\begin{tabular}{|l|l|l|l|c|c|}
\hline \multicolumn{1}{|c|}{ Rus I } & N & Sig. & \multicolumn{1}{|c|}{ Rus II } & N & Sig. \\
\hline Par 1 PreTLU - PostTLU & 19 & .036 & Par 1 PreTLU - PostTLU & 19 & .001 \\
Par 2 PreFB - PostFB & 19 & .001 & Par 2 PreFB - PostFB & 19 & .000 \\
Par 3 PreMC - PostMC & 19 & .003 & Par 3 PreMC - PostMC & 19 & .000 \\
Par 4 PreGJ - PostGJ & 19 & .059 & Par 4 PreGJ - PostGJ & 19 & .000 \\
\hline
\end{tabular}

Table 6: Results of $T$-test

\section{Discussion and Conclusions}

The results of the statistical analyses showed that participants significantly improved at post-test scores and confirmed that task design was efficient in terms of focus on form. The only exception was the grammaticality judgement test in the group Rus I. Ellis (Ellis, 2005) has claimed that this type of test measures explicit metalinguistic knowledge. In the light of this hypothesis, the obtained results could mean that learners had not acquired explicit knowledge of the Russian case system yet.

Although the overall results of the pilot study were positive, some errors had been committed in the design of two tasks. First, it was not taken into account that the complexity of the Russian language often requires so much learner attention that they barely can handle the increase in cognitive load. It led to the failure in the performance of one of the tasks. Second, learners' current knowledge was sometimes overestimated and the code complexity of some tasks was found to be higher than expected.

On the basis of this pilot study, several decisions can be made regarding task design in Russian for learners with a low level of proficiency:

1. The amount of new vocabulary and grammar forms that are necessary to perform the task should be carefully controlled.

2. Since vocabulary and grammar forms that are not new for learners can still cause problems in task performance, the amount of input and pre-task activities aimed at the activation of the previous knowledge has to be increased.

3. The cognitive load of a task can be increased only when learners are familiar with the language material necessary to perform the task and when they have a good command of task-essential language.

The current study has some obvious limitations, such as a low number of participants, the lack of a delayed post-test, and the use of only one accuracy measure (target-like use of case forms and verbs of movement) in the analysis of the written production. Further research could involve audio recording of learners performing the tasks, oral assessment tasks, and, finally, affective variable questionnaires that could help obtain information about the learners' perception of task difficulty.

\section{References}

Ellis, R. (2003). Task-based language learning and teaching. Oxford: Oxford University Press.

Ellis, R. (2005). Measuring implicit and explicit knowledge of a second language. Studies in Second Language Acquisition, 141-172.

Long, M. (2015). Second language acquisition and task-based language teaching. Oxford: Wiley Blackwell. 
Loschky, L., Bley-Vroman, R. (1993). Grammar and task-based methodology. In G. C. Gass, Tasks and language learning. Integrating theory and practice (pp. 123-167). Clevedon: Multilingual Matters.

Nunan, D. (2004). Task-based language teaching. Cambridge: Cambridge University Press.

Pica, T., Kanagy, R., Falodun, J. (1993). Choosing and using communication tasks for second language instruction. In G. C. Gass, Tasks and language learning. Integrating theory and practice (pp. 9-34). Clevedon: Multilingual Matters.

Robinson, P. (2001). Task complexity, cognitive resources, and syllabus design: A triadic framework for examining task influences on SLA. In P. Robinson, Cognition and second language instruction (pp. 287-318). Cambridge: Cambridge University Press.

Robinson, P. (2011). Task-based language teaching: A review of issues. Language Learning, 1-36.

Skehan, P. (1998). A Cognitive Approach to Language Learning. Oxford: Oxford University Press.

Van den Branden, K. (2013). Task-based language teaching and learning. In P. Robinson, The Routledge Encyclopedia of Second Language Acquisition (pp. 628-632). New York: Routledge. 